in social judgment, the management of mind, the limits of technical education, the development of post-primary education, education and the Christian view of the world, the tyranny and liberty of books, geography and economic theory, the institution in modern society, education and awareness. At first sight these nine themes appear unconnected. They turn nevertheless upon a three-fold conception of the aims and obligations of education, namely, that it should fit us to get a living, to live a life and to mould a world. If those aims, in that order, be accepted (and we doubt whether the acceptance is as widespread as the author believes) the link between the addresses becomes plain.

We hope the book will be read by educationists because it contains the kind of challenge they should expect when a mind as fresh and vigorous as Sir Josiah Stamp's examines their methods and purposes. His remark that he is "tired of people who pride themselves on their general ability and culture who have never been through the personal discipline of accurate and fine performance in some particular", might well be carefully studied by those to whom the word 'culture' represents something difficult to find in our modern industrial and commercial world. We hope, too, that the book will be read by scientific workers so that they may realize the danger to their own work if they lack awareness of the work of others, and of the interdependence of all branches of learning.

J. W. M.

International Institute Examinations Enquiry

A Conspectus of Examinations in Great Britain and Northern Ireland. By Sir Philip Hartog, with the assistance of Grace Roberts. Pp. xiv +182. (London : Macmillan and Co., Ltd., 1937.) 3s. 6d. net.

7 HE field (or jungle) covered by this bird's-eye view includes an amazing variety of tests applicable to examinees of all ages from ten upwards. The bird in question being Sir Philip Hartog, it is scarcely necessary to say that the view is comprehensive, keen, intelligent and lucid. It comprises (a) the Local Education Authorities', (b) the secondary school, and (c) the university examinations; also (d) those conducted under statutory authority for admission to professions or callings, and $(e)$ a list of examining bodies classified under general subject headings-accountancy, advertising, aeronautics. . . . As regards $(a),(b)$ and $(c)$, the subjects of examination are set forth in detail. Incidentally, some light is thrown on methods. A glance through $(a)$ shows that 'intelligence tests' are widely used as well as school records and interviews. In the university section, prominence is given to the growing practice of conferring degrees either wholly or partly for a thesis.

As regards $(d)$ the various procedures adopted by Parliament in conferring authority to admit to certain callings are shown in brief without detailed lists of subjects of examination. This and the other publications ("English Bibliography of Examinations", "Examination of Examinations", "Essays on Examinations", "Marks of Examiners") of the Examinations Enquiry Committee (chairman, Sir
Michael Sadler; director, Sir Philip Hartog) should be most helpful to all whose business it is to see that these multitudinous sifting processes function as beneficially as may be. The committee, and parallel committees in other countries, owe their existence to the International Institute of Teachers College, Columbia University and certain Carnegie endow. ments.

Science and Social Welfare in the Age of Newton By Prof. G. N. Clark. Pp. vii +159. (Oxford : Clarendon Press ; London : Oxford University Press, 1937.) 6s. net.

A FACTOR in the growing concern of scientific A workers with the social consequences of their work has been the realization that the extent of their work is itself largely determined by the nature of the society in which they work. In this interesting little study, Prof. G. N. Clark shows us, however, that this is no new phenomenon and that scientific progress was conditioned by the state of society as truly in the age of Newton as it is to-day. In a series of chapters dealing with science and technology, economic incentives to invention, the social and economical aspect of science and the social control of technological improvement, which represent the substance of four lectures delivered in the University of London in 1936, he gives a highly suggestive survey of the way in which not only has applied science influenced the whole structure of society but also science, and scientific methods, have been shaped and sharpened by what they took over from the arts and crafts and from the practice of merchants.

Prof. Clark traces five distinct groups of influence upon science, those from economic life, from war, from medicine, from the arts and from religion, all reinforcing or clearing the way for the sixth great motive, the disinterested love of truth, which it is the special social function of the universities to liberate from the pressure of other motives. In the final chapter he surveys the position of social science and shows that already at the beginning of the eighteenth century it appeared to have an established position and a great future. His little volume appears at an opportune moment and has claims on the interest of all those scientific workers who are concerned with the increasing co-operation of science and economic life.

R. B.

\section{Philosophy and Psychology}

The Human Situation:

the Gifford Lectures delivered in the University of Glasgow, 1935-1937. By W. Macneile Dixon. Pp. 438. (London: Edward Arnold and Co., 1937.) 18s. net.

U OWEVER difficult and technical philosophy may be to-day, its purpose is still practical : know. ledge and happiness are and remain fundamental urges of man, which cannot be brushed aside by a simple pronouncement of modern science that man is completely unimportant in the economy of the world. The only way to replace philosophy in that lofty station it should occupy in our interests, is to bring it back to the market place without stripping it of 